\title{
Sex Determination of Bovine Embryos by the Polymerase Chain Reaction Using Y-Specific Primers
}

\author{
Kyozo UTSUMI, Takeshi KAWAMOTO, Jin Hoi KIM, \\ Akira IRITANI, Akira SAKAI ${ }^{1)}$ and Tohru KOMANO ${ }^{1)}$ \\ Department of Animal Science, College of \\ Agriculture, Kyoto University, ${ }^{1)}$ Department of \\ Agricultural Chemistry, College of Agriculture, \\ Kyoto University
}

\begin{abstract}
The sex of embryos was determined by the polymerase chain reaction (PCR) method using the DNA fragment of a sex-related gene or Y-chromosome specific nucleotide sequence. By using the DNA fragment of the human sex determinant (SRY), cells of male humans, rabbits, rats, mice and goats can be distinguished from the female cells of each animal. By PCR using DNA of the mouse sex determinant (Sry), male cells of mice and rats were selected from the cell population. The sex of cattle cells and goat cells could be determined by PCR using BOV97M (cattle Y-specific repeated DNA sequence). The DNA preparation of rabbit or cattle embryos was amplified by the primer of either SRY or BOV97M, and the embryonic sex was successfully determined. The sex of the embryos predicted using the H-Y antibody or sex chromosome was confirmed by PCR analysis for biopsy of the trophoblastic cells. The bovine growth hormone gene $(\mathrm{bGH})$ was used as an internal standard of cattle-specific DNA fragment. High efficiency and accuracy for embryo sexing was attained from biopsied embryos. Three of the 8 (38\%) biopsied embryos transferred into the recipient resulted in pregnancy, and the sex of 2 calves born was the same as expected.
\end{abstract}

Key words: PCR, SRY, Y-specific DNA, bovine, H-Y antibody

(J. Reprod. Dev. 38: 35-43, 1992)

S ex differentiation, diagnosis of fetal sex and determining embryonic sex, especially sexing of pre-implantation embryos are important in animal husbandry. Traditionally, the sex of the embryo has been predicted by the histological detection of sex chromatin or sex chromosome for embryonic cells. The male specific antibody has been applied to embryo sexing by indirectimmunofluorescence [1], in situ hybridization [2], Southern/dot blotting [3], or by preventing blastocoel formation [4], however, no effective methods for embryo sex determination have been established, because of the low efficiency of both histological methods and antibody assay. Y-specific

Accepted for Publication: August 12, 1991

Correspondence: K. Utsumi
DNA is now available as a probe for embryo sex determination, and it should be useful for bovine embryo sex determination [5]. The SRY gene construction which is considered to direct sex differentiation was cloned and introduced into a mouse pronuclear egg. The SRY gene induced male young with $\mathrm{XX}$ sex chromosome complement [6], which suggested that the SRY gene used here is related to sex differentiation. Application of genetic type to DNA diagnosis is utilizable, although the amount of DNA is so low that radio-isotopes must be used. However, the polymerase chain reaction (PCR) which amplifies repeatedly the targeted DNA enables effective detection of DNA. By the PCR methods, a targeted DNA can be amplified million times during several hours by PCR. On the basis of the 
principles, sex of human preimplantation embryo was identified by the PCR method using the human Y-specific DNA fragment [7]. In the PCR method for sex determination, the DNA fragment of either the testis-determining factor (TDF) or highly conserved repeated DNA sequence on $\mathrm{Y}$ chromosome have been used as primer. But comparative studies have not been made on the PCR analysis for embryo sexing with the various primers related to TDF.

In this study, the sex of embryos of several animal species including cow was examined by PCR using TDF candidate gene such as mouse Sry DNA sequence [8] and human SRY DNA sequence [3] or bovine Y-chromosome-specific DNA sequence [9]. Especially, the sex of bovine embryos predicted by the H-Y antibody and by chromosome analysis was confirmed by this PCR procedure. Biopsied embryos for DNA analysis were transferred into recipients to prove fetal sex.

\section{Materials and Methods}

\section{Preparation of high molecular genomic DNA}

(1) Extraction of DNA from liver tissue and blood cells: DNA extraction from liver tissue and blood cells were carried out by either of the 2 following methods. Method I (Molecular cloning (1), [10]) was done as reported with some modification. Supernatant from phenol-chloroform extraction by using tissue homogenater was incubated with $12.5 \mu \mathrm{l}$ of $4 \mathrm{mg} / \mathrm{ml}$ RNase (Sigma) for $20 \mathrm{~min}$. Each of samples were precipitated with $2.5 \mathrm{vol}$ ethanol plus 1/10 $3 \mathrm{M}$ Sodium-Acetate and dried in dessicater. A portion of the redissolved sample was quantiated the amount of DNA by spectrophotometric measurement. One handred to $200 \mathrm{ng}$ DNA was presented to PCR procedure. Methods II was done according to the methods of Lin $e t$ al. [11]. Three $\mathrm{mm}$ tissue was incubated with $100 \mu \mathrm{l}$ of $1 \mathrm{mg} / \mathrm{ml}$ collagenase (Sigma, Type IA Lot $30 \mathrm{H} 6849$ in $50 \mathrm{mM}$ Tris-HCl pH 8.0) at 45 to $55 \mathrm{C}$ for $3 \mathrm{~h}$. DNA was extracted one time each with phenol, phenol/chroloform (1:1) and chloroform/ isoamylalchol (24:1). Then, a portion of more than $1 \mu \mathrm{l}$ of the DNA supernatants was applied to PCR.

(2) Extraction of embryonic DNA; To remove the zona pellucida, morula to blastocyst stage embryos of rabbits, mice, rats and cows were treated by either acidic tyrode $(\mathrm{pH} 4.0)$ or $0.5 \%$ pronase in PBS (-) containing BSA or PVP at $37 \mathrm{C}$ for $5 \mathrm{~min}$. Zona-free embryos were washed 2 to 3 times with $3 \mathrm{mg} / \mathrm{ml} \mathrm{BSA}$ in PBS $(-)$, then transferred into $0.6 \mu \mathrm{l}$ Eppendorf tube containing $10 \mu \mathrm{l}$ autoclaved water and boiled at 95C for $5 \mathrm{~min}$ to extract DNA. In vitro cultured rabbit embryos were used to avoid the mucine layer, and in vitro matured fertilized and cultured bovine embryos were used, according to our routine methods [12].

(3) Extraction of biopsied embryonic-cells DNA; Bovine blastocysts were recovered from a superovulated donor cattle. Embryos were split into 2 parts or the trophoblastic cells (10 to 20 cells) were biopsied with a micro-metal blade using a micromanipulater. Morula stage embryos obtained from the superovulated donor were incubated with the $\mathrm{H}-\mathrm{Y}$ antibody for $6 \mathrm{~h}$ at $37 \mathrm{C}$, to classify the male or female embryos according to the method reported before [13]. DNA was extracted from biopsied embryonic cells.

\section{Synthesis of primer}

Highly conserved rabbit's homologous DNA sequences within the SRY regions of human $\mathrm{Y}$ chromosome was selected and synthesized using a DNA/RNA synthesizer (Aplied biosystems Japan; 394 DNA/RNA synthesis) as a primer-I. This primer-I (Sry-1: 5'-GTGAAGCGACCCATGAACGCA-3' and 5'-CGGGTATTTCTCC TGTGCAT-3', Sinclar et al. [8]) amplified 198 base pairs. As primer-II, the DNA sequence outside the Sry-conserved are of mouse Y chromosome was selected and synthesized. This primer-II (Sry-2: 5'-GAGAGCATGGAGGGCCAT-3' and 5'CCACTCCTCTGTGACACT-3', Gubby et al., [3] amplified 266 base pairs. As primer-III, the bovine Y chromosome specific DNA sequence was selected and synthesized. This primer (BOV97M: 5'-GATCACTATACATACACCACT-3' and 5'GGCTATGCTAACACAAATTCTG-3', Miller \& Koopman, [9] amplified 141 base pairs. Furthermore, as a positive control for bovine embryonic cells, DNA sequence of the bovine growth hormone gene (bGH : 5'-GGGAGGGTTCCGAAGGC-3' and 5'-AGGAAGGAGGTTTCAAAAGG-3' or 5'-CAAAGAGTTTGTAAGCTCCCAAGG-3' and 5'-GAGGTTGCCACTCACTGATTTCTG-3', Woychik et al., [14]) was used. These primers amplified 754 or 369 base pairs. Each primer was prepared to $100 \mathrm{ng} / \mu \mathrm{l}$ DNA by diluting with 
autoclaved water.

Cytoplasmic DNA amplification by PCR and the detection of amplified DNA

Extracted DNA, primer, dNTP, PCR buffer and Taq polymerase (Toyobo, Japan) were mixed as follows: several pg to $1 \mu \mathrm{g}$ genomic DNA, $50 \mathrm{pmol}$ primer (20 pmol Y-specific primer and $50 \mathrm{pmol}$ bovine specific primer) and 1.5 to 2.5 unit Taq polymerase were mixed to make $50 \mu \mathrm{l}$, and then filter-sterilized $5 \mu \mathrm{l} \mathrm{PCR}$ buffer $(50 \mathrm{mMKCl}, 10$ $\mathrm{mM}$ Tris-HCl, $\mathrm{pH} 8.3$ ) and, each $200 \mu \mathrm{M}$ of dATP, dGTP, dCTP, dTTP were added to the reaction mixture. Finally, several drops of mineral oil were added to cover the reaction mixture to prevent the evaporation of the mixture. The reaction mixture was accomplished automatically with DNA thermal cycler (Astec Co., Ltd: program temp control system PC-700), and then were denatured at $95 \mathrm{C}$ for 5 min followed by 30 cycles consisting of denaturation for $1 \mathrm{~min}$ at $95 \mathrm{C}$, annealing for $2 \mathrm{~min}$ at $55 \mathrm{C}$ and primer extension at $72 \mathrm{C}$ for $3 \mathrm{~min}$. After the last cycle, samples were incubated for a further $10 \mathrm{~min}$ at $72 \mathrm{C}$ for $10 \mathrm{~min}$ to complete perfectly DNA synthesis.

Ten $\mu$ l of the amplified product of the DNA sample was electrophoresed on $2.4 \%$ agarose gel with 1 to $2 \mu$ l DNA digested with lambda-Hind III (Takara, Japan) as a molecular marker. The resulted products were stained by ethidium bromide and were visualized under ultraviolet light. If the Y-chromosome specific 198-basepair products (SRY), 145-base pair products (Sry) or 140basepair products (BOVM) except female's samples were visible, the cell samples were considered to be derived from a male.

\section{Embryonic DNA amplification and its detection}

Embryonic DNA amplification for rabbits, mice and rats, and cows which was carried by using primer-I (Sry-1), primer II (Sry-2), and primer III (BOV97M), respectively. A portion of the embryonic DNA from an embryo mixed with 120 to $600 \mathrm{ng}$ primer and $0.2 \mathrm{mM} \mathrm{dNTP}$ as substrates in the PCR buffer solution $(10 \mathrm{mM}$ Tris- $\mathrm{HCl} \mathrm{pH}$ $8.3 ; 50 \mathrm{mM} \mathrm{KCl} ; 1.5 \mathrm{mM} \mathrm{MgCl} 2 ; 0.01 \%$ geratin) and then boiled for $5 \mathrm{~min}$. The targeted DNA in the reaction mixture was amplified by PCR followed after adding 0.5 to 1.5 unit Taq polymerase.

The biopsied samples of bovine embryonic cells were washed with PBS (-) containing $4 \mathrm{mg} / \mathrm{ml}$
PVP, boiled for $5 \mathrm{~min}$, and its DNA was amplified using bovine specific primer $(\mathrm{bGH})$ as a positive control, besides the male specific primer.

Estimation of viability of bovine biopsied embryos

One of the biopsied embryos was analyzed for karyotyping to confirm the embryo sex by PCR. The others were transferred into recipients immediately or after cryopreservation to prove they could develop into calves. Karyotype of embryonic cells was a analyzed by the method of Tarkowsky [15]. Embryonic sex pre-determined by malespecific antibody was reexamined by PCR using the biopsied embryos. The biopsied embryos were cryopreserved by our routine methods using glycerol as cryoprotectant [16]. Fresh or cryopreserved embryos exposed to male-speicific antibody and the trophoblast cells of which had been biopsied were transferred into the recipient to confirm that they could develop to full term.

\section{Results}

\section{Sex determination of somatic cell}

Fig. 1-a shows the electrophoretic pattern of somatic cells DNA amplified by PCR using Sry- 1 as a primer (primer-1). The resulted banding of 198 bp was detected in only the male somatic cells (blood or liver) of humans, rabbits, mice, rats and goats, except bovine male cells. In ovine cells, however, the banding of $198 \mathrm{bp}$ was detected in both male and female cells. Except for ovine cells, no bands related to Sry-1 were found in female cells tested here. These findings suggest that PCR using Sry-1 used as primer in human testis determination enabled the identification of sex in human, rabbit, mouse, rat and goat cells.

Fig. 1-b shows the electrophoretic pattern of cellular DNA amplified by PCR using Sry-2 (primer-2). A band of 266 bp was detected in the male mouse and rat cells, but not in male human, bovine and rabbit cells. No banding was detected in female cells tested here. These findings suggested that PCR using Sry-2 (partial DNA sequences of mouse Sry) as a primer (primer-2) enables cell sex determination of mice and rats cells.

Fig. 2 shows the electrophoretic pattern of bovine cellular DNA amplified by PCR using BOV97M, bovine Y-chromosome specific DNA sequences. A $141 \mathrm{bp}$ band was detected in bovine 


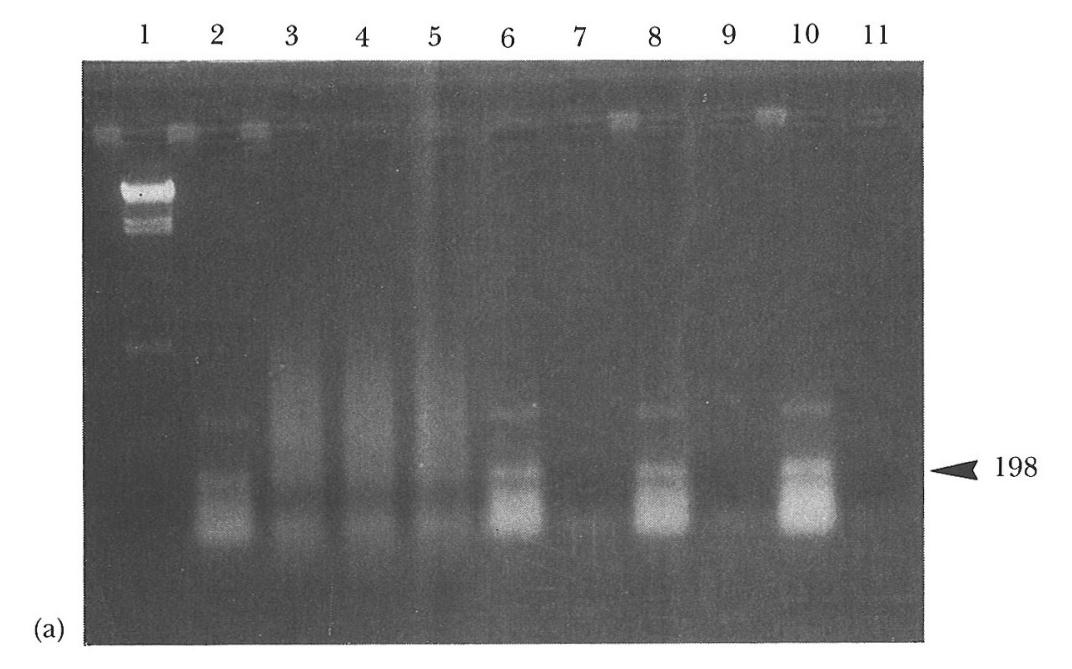

(b)

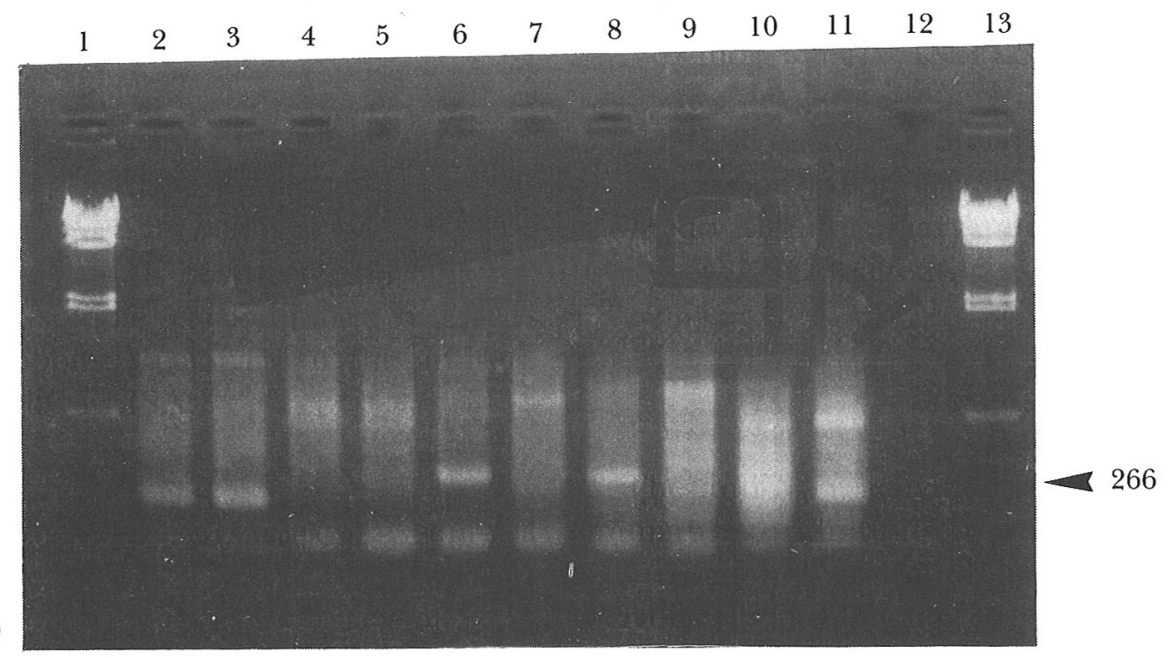

Fig. 1. PCR analysis of genomic DNA from human, cattle, goat, sheep, rabbit, mouse and rat cells showing SRY (Sry-1: 198 bp) or Sry (Sry-2: 266 bp) band.

On upper agarose gel electrophoresis (a), male cells of humans (2), goats (6), mice (8) and rats (10) gave SRY-band, but female cells of humans (3), goats (7), mice (9) and rats (11) gave no bands specific for SRY. In cattle, neither male (4) nor female (5) cells gave a band related to SRY.

On lower agarose gel electrophoresis (b), male cells of mouse (6) and rat (8) gave a Sry-band, while female cells of mouse (7) and rat (9) gave no bands specific for the Sry-band. No bands related to the Sry were produced in either male or female cells of humans $(1,2)$, cattles $(3,4)$ or rabbits $(10,11)$.

male cells, but not in bovine female cells (Fig. 2-a). Three bands, 150, 250 and 500 bp were detected in male goat cells, not in female goat cells. Two bands of $200 \mathrm{bp}$ and $400 \mathrm{bp}$ were detected in male and female ovine cells, a band of $100 \mathrm{bp}$ was detected only in male ovine cells. Thus, BOV97M and bovine $\mathrm{Y}$-chromosome specific DNA sequences enable sex determination of bovine and ovine cells. There was no difference in the electrophoretic patterns between the DNA samples derived from the 2 DNA extraction methods, mehtod 1 (original method) and method 2 (conventional method). Since DNA could be extracted from cells sufficiently by methods 2 when DNA was amplified by PCR, it was used for DNA extraction. 


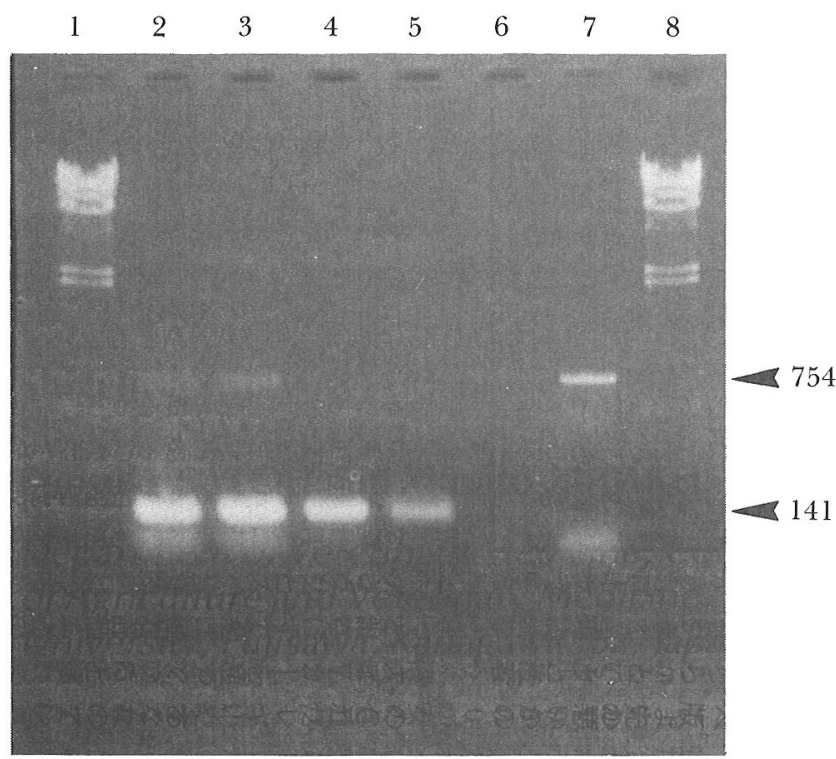

(a)

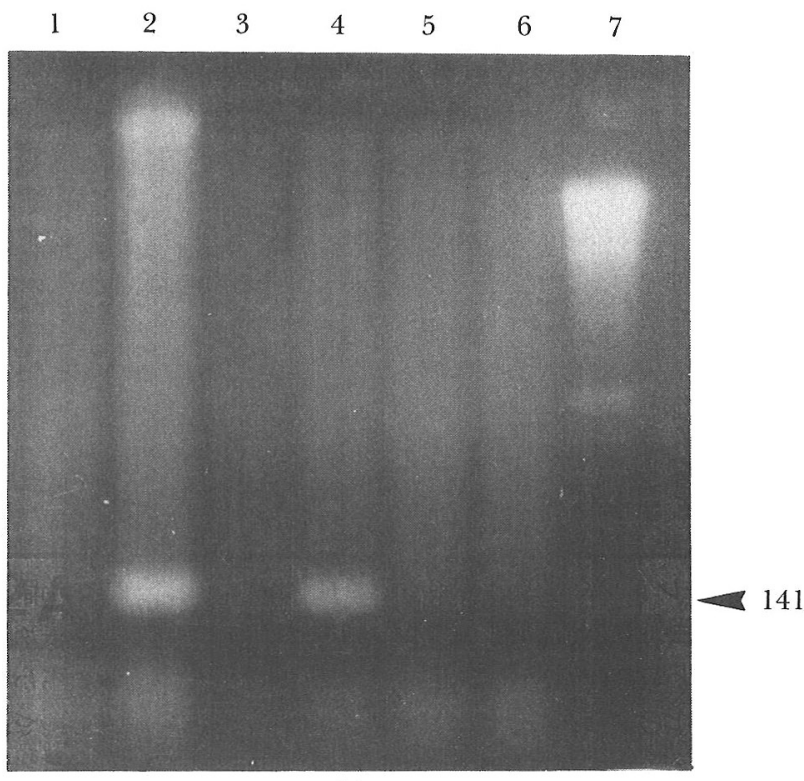

(b)

Fig. 2. PCR analysis of genomic DNA from cattle, goat and sheep cells showing BOV97M (BV-1: $141 \mathrm{kbp}$ ).

On right agarose gel electrophoresis (b), male cells of cattle (2) and goat (4) gave a BV-1 band, but female cells of cattle (1) and goat (3) gave no bands specific for BV-1. In sheep, neither male (6) nor female (5) cells gave bands related to the $\mathrm{BV}-1$ band.

On left agarose gel electrophoresis (a), male cells of cattle (2, 3, 4 and 5) gave both a BV-1 band and GH-1 (754 $\mathrm{kbp}$ ) band, but female cells (7) of cattle gave only the GH-1 band.

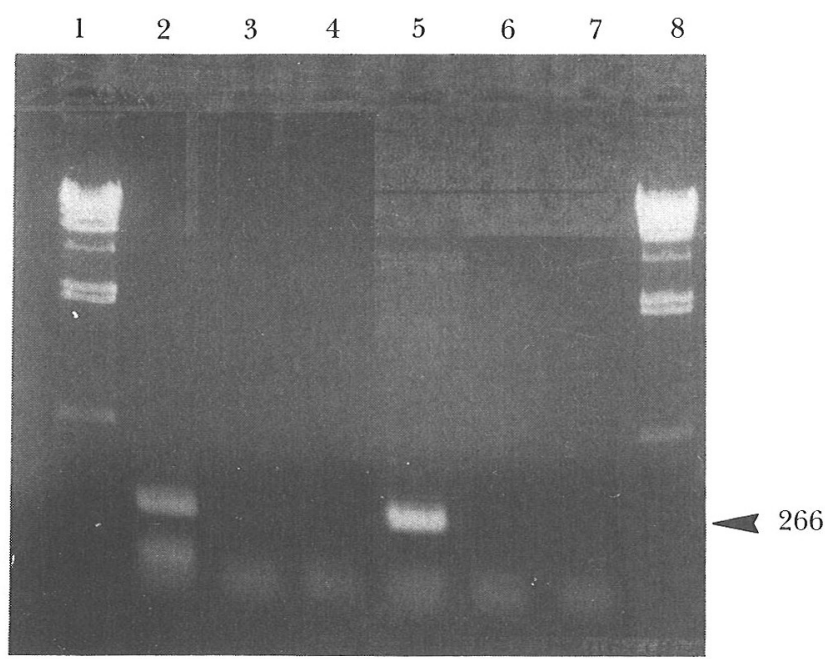

(a)

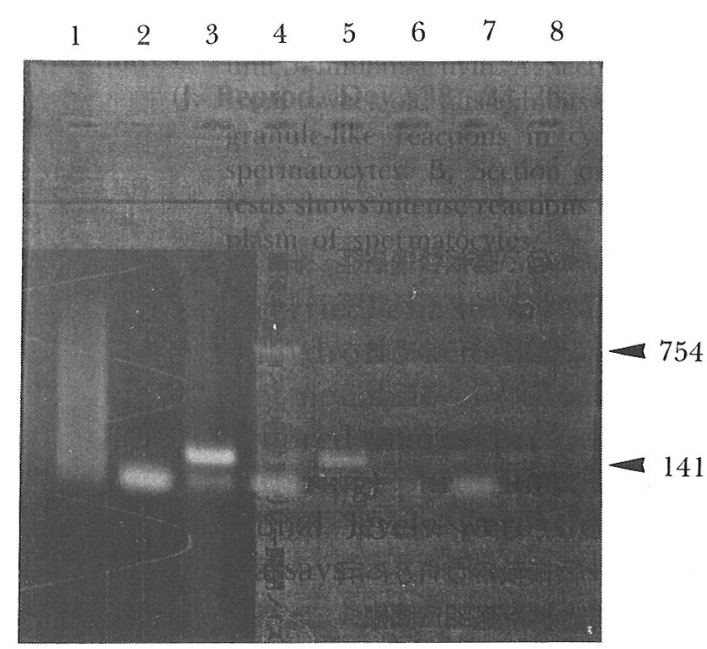

(b)

Fig. 3. PCR analysis of genomic DNA from rabbit or cattle embryos showing Sry-1 (266 kbp) or BOV97M (141 kbp) band.

On right agarose gel electrophoresis (b), cattle embryonic DNA in No. 3 lane gave a band corresponding to cattle male cells (No. 5), while cattle embryonic DNA at No. 2 and No. 4 lane gave no bands as with cattle female cells (No. 65), accompanied with the GH-band (754 kbp).

On left agarose gel electrophoresis (a), rabbit embryonal DNA in lane No. 2 gave a band corresponding to rabbit male cell (No. 5), while rabbit embryonal DNA at No. 3 and No. 4 lane gave no bands as with rabbit female cells (No. 5). 
Table 1. Determination of embryonal sex by PCR using different kinds of primer

\begin{tabular}{|c|c|c|c|c|}
\hline \multirow{2}{*}{$\begin{array}{l}\text { Animal } \\
\text { species }\end{array}$} & \multirow{2}{*}{$\begin{array}{l}\text { Primer } \\
\text { used for } \\
\text { assay }\end{array}$} & \multirow{2}{*}{$\begin{array}{l}\text { No. of } \\
\text { embryos } \\
\text { examined }\end{array}$} & No. of embryos & sex-determined \\
\hline & & & Male & Female \\
\hline Bovine & BV-1, GH-1 & 38 & 18 & 20 \\
\hline Mouse & Sry-2 & 12 & 7 & 5 \\
\hline Rat & Sry-2 & 7 & 4 & 3 \\
\hline Rabbit & Sry-1 & 16 & 9 & 7 \\
\hline
\end{tabular}

Morula to blastocyst stage embryos were used for the assay

Table 2. Sex determination of cattle blastocyst stage embryos sexpredicted using PCR

\begin{tabular}{llccc}
\hline $\begin{array}{l}\text { Methods } \\
\text { of sex } \\
\text { prediction }\end{array}$ & $\begin{array}{l}\text { Predicted } \\
\text {-sex of } \\
\text { embryos }\end{array}$ & $\begin{array}{c}\text { No. of } \\
\text { embryos } \\
\text { tested }\end{array}$ & & Sex determination by PCR \\
\cline { 5 - 5 } \cline { 4 - 5 } H-Y antibody & $\mathrm{H}-\mathrm{Y}(+)$ & 15 & 14 & Female \\
H-Y antibody & $\mathrm{H}-\mathrm{Y}(-)$ & $20^{\text {a) }}$ & 3 & 1 \\
\hline Chromosome & $\mathrm{XY}$ & 4 & 4 & 16 \\
Chromosome & $\mathrm{XX}$ & 5 & 0 & 0 \\
\hline
\end{tabular}

a) one embryo (partially biopsied trophoblastic cell) was not sexed.

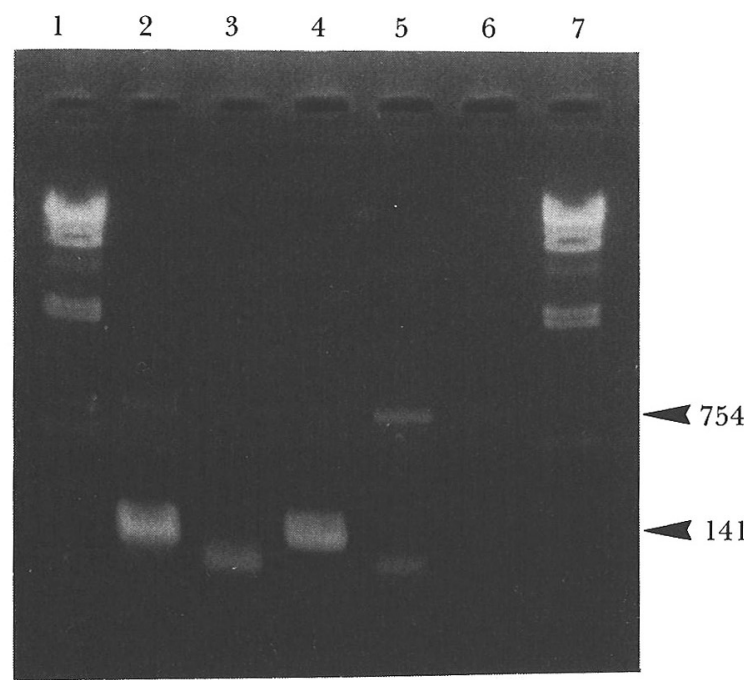

(a)

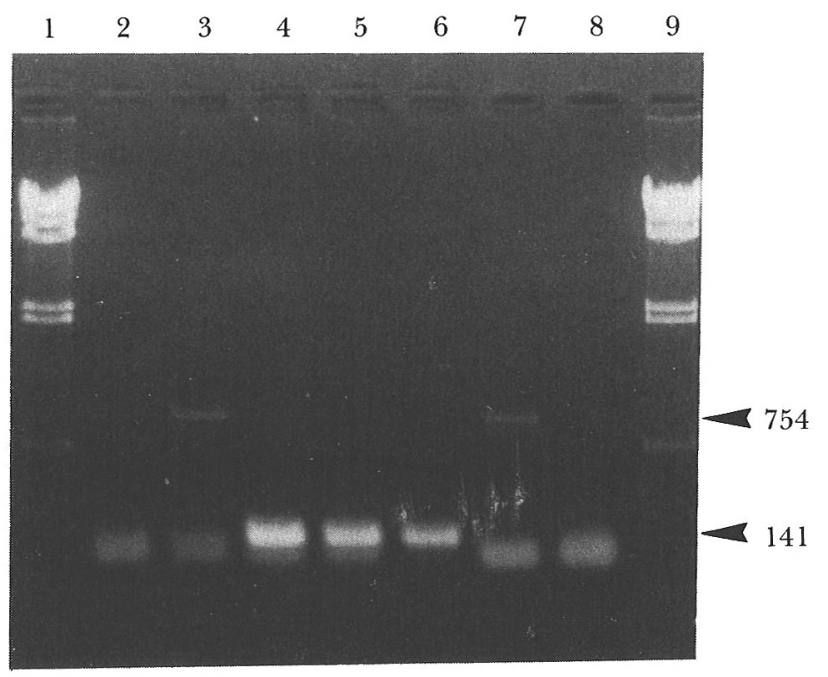

(b)

Fig. 4. PCR analysis of sex-predicted cattle embryos using the BOV97M primer and GH-1 primer.

On right agarose gel electrophoresis (b), H-Y positive embryonal DNA at No. 4 and No. 5 lane gave a band corresponding to male call (No. 6), while the H-Y negative embryonal DNA at No. 1 and No. 2 lane lacks those bands, accompanied by the GH-1 band (754 kbp).

On left agarose gel electrophoresis (a), XY-chromosome embryonal DNA at No. 2 lane shows a band corresponding to male cell (No. 4), while XX-chromosome embryonal DNA at No. 3 lane lacks those bands, accompanied with the GH-1 band (754 kbp). 
Table 3. Efficiency of sex determination by PCR for whole embryos or biopsied cells in cattle

\begin{tabular}{lcccc}
\hline $\begin{array}{l}\text { Condition } \\
\text { of embryos } \\
\text { tested }\end{array}$ & $\begin{array}{c}\text { No. of } \\
\text { embryos } \\
\text { tested }\end{array}$ & \multicolumn{3}{l}{ No. of successful sexing by PCR } \\
\cline { 3 - 5 } & 45 & $45(100)$ & 24 & 21 \\
\hline Whole & 19 & $19(100)$ & 8 & 11 \\
Half & 13 & $12(92)$ & 5 & 7 \\
\hline Partial & Total $(\%)$ & Male & Female \\
\hline Total & 77 & $76(99)$ & 37 & 39 \\
\hline
\end{tabular}

a) Trophoblastic cells were biopsied.

\section{Sex determination of embryonic cells}

The sex of the embryonic cells was analyzed. Fig. 3-a shows the electrophoretic pattern of rabbit embryonic cell DNA amplified by PCR using Sry-1. Bovine embryonic cell DNA was amplified by PCR using BOV97M and GH-1 as primers (Fig. 3-b). Banding of embryonic DNA in both species appeared male-specific, as was that of male somatic cell DNA. For bovine embryonic cells, the $754 \mathrm{bp}$ band of DNA (DNA of bovine growth hormone gene) which was amplified as an internal standard was detected in both male and female samples, while the $141 \mathrm{bp}$ banding was detected only in male embryonic cell DNA. Considering the 50 to 50 sex ratio in the embryonic cell tested here (Table-1), the sex of mouse and rat embryos could be predicted by PCR using Sry (Sry-2), and the sex of rabbit embryos could be predicted by PCR using SRY (Sry-1), and bovine embryos by PCR using BOV97M (BOV-1). When bovine embryos sexpredicted by $\mathrm{H}-\mathrm{Y}$ antibody were again analyzed by PCR (Fig. 4-b), 14 of the 15 embryos presumed as male and 16 of the 20 embryos presumed as female were of the same sex as presumed (Table2). DNA of whole embryos or of the biopsied embryos was amplified by PCR, because the biopsed embryos were transferred into a foster mother.

\section{Sex determination in biopsied embryonic cell}

To confirm the sex of biopsied embryos predicted by PCR, the sex chromosome was examined. Chromosomal sex in all 4 biopsied embryos coincided with the sex (Fig. 4-a) of the biopsied embryo sex-predicted by PCR methods (Table 2). The sex of all biopsied cells except for one sample of a partially removed trophoblastic cell could be predicted by PCR (Table 3). To determine the ability of biopsied embryos to develop to full term, biopsied embryos which were in vitro cultured to reform the blastocoel within several hours were transfered into a synchronized recipient. Three of 8 recipient cattle became pregnant, 2 calves of which were born with the same sex as predicted.

\section{Discussion}

The sequence related to the sex-determining region should be selected as a primer for sexing. Several primers such as PAR neighboring region (monkey; Palm et al., [17] and ZFY (human; Page et al., [18]) near the TDF on Yq chromosome or DYZ-1 (human: Nakahori et al., [19]) and DYZ-2 (human; Weisenbach et al., [20] on the repeated sequence of $\mathrm{Yp}$ chromosome have been used for making sex determinations using somatic cells. There is little research on the embryo sexing using a primer related to a sex determinant such as Sry. Furthermore, the findings obtained previously were varied in every experiment, because the sequence of amplified DNA differed, with the variation of the primer used then.

Human Sry-1 [8] enabled amplification of the DNA of human and rabbit male cells, and mouse Sry-2 [3] enabled amplification of the DNA of mouse and rat male cells. The sex determining factors were preserved in all species. Sry-1 could not amplify the DNA of bovine male cells, which was amplified only by BOV98M [9]. These findings showed that the DNA sequence of SRY used here as a primer was not entirely in accordance with that of the bovine SRY region. Therefore, the bovine DNA sequence specific for sex determination was not amplified. Otherwise, when a minor change of the DNA sequence such as point mutation, small deletion or insertion occurred in the target region according to the amplified DNA [21], such DNA sequences could not be amplified.

To improve the accuracy of analysis for sexing, double primers such as inner primer [22] or species-specific primer for PCR [23] are being used. In this experiment, 2 primers, bGH- and male specific-DNA for bovine embryonic sex determination were used. The bands derived from bGH confirmed that the tested cells were bovine 
embryonic cells. In this case, to avoid the quantitative difference beyond detective limitation between amplified DNA by the two primers, the concentration of bGH as primer of positive control was prepared to be $600 \mathrm{ng}$, in contrast to $150 \mathrm{ng}$ of BVD98M as a male specific primer.

Coincidence of the resulting embryonic sex obtained by PCR using the male specific primer with the sex estimated by the $\mathrm{H}-\mathrm{Y}$ antigen or sex chromosome reflects the accuracy of sex determination by both analytical methods. The minimum volume (embryonic cell numbers) of tested material essential for the exact detection of targeted DNA by DNA amplification was 10 embryonic cells [2]. Here, it was too indicated that biopsy derived from a third part of the trophoblastic cell in the tested blastocyst, consisting of 10 to 20 cells enables accurate embryonic sex determina- tion.

Biopsied embryos were transferred into the recipient cattle, $36 \%$ of which become pregnant. This suggested that the manipulation for biopsy did not affect drastically the viability and the biopsied embryos developed to full term. However, no viable embryo could be obtained by transfer of the biopsied embryos after frozen-thawed. Compared to the 40 percent pregnancy obtained using biopsied and frozen-thawed embryos [2], our failure with frozen-thawed embryos might be due to the pre-treatment such as 24-h in vitro culture of embryos with H-Y antibody for embryo sexing, as well as biopsied procedure. Herr \& Reed (1991, [24]) pointed out that the complexity of the biopsy procedure and the low freezability of biopsied embryos might be limiting factors for the diagnosis using DNA.

\section{References}

1. White KL, Linder GM, Anderson GB, Bondurant RH. Cytolytic and fluorescent detection of $\mathrm{H}-\mathrm{Y}$ antigen on preimplantation mouse embryos. Theriogenology 1983; 17: 701-750.

2. Bondioli KR, Ellis SB, Pryor JH, William MW, Harpold MM. The use of male-specific chromosomal DNA fragments to determine the sex of bovine preimplantation embryos. Theriogenology 1989; 31: 95-104.

3. Gubbey J, Collignon J, Koopman P, Capel B, Economou A, Münsterberg A, Vivian N, Goodfellow P. Lovell-Badge A. A gene mapping to the sex determining region of mouse $\mathrm{Y}$ chromosome is a member of a novel family of embryonically expressed genes. Nature 1990; 346: 245-250.

4. Utsumi K, Sato E, Iritani A. Sexing of rat embryos with antisera specific for male rat. J Exptl Zool 1991; 260: 99-105.

5. Higashi Y, Iwaya M, Ogawa S. Newly founded bovine male-specific DNA fragment amplified by polymerase chain reaction. Jap J Anim Reprod 1991; 37: 115-120.

6. Koopman P, Gubbay J, Vivian N, Goodfellow P, Lovell-Badge R. Male development of chromosomally female mice transgenic for SRY. 1991; 351: 117-121.

7. Kogan SC, Doherty M, Gistschier J. An improved methods for prenatal diagnosis of genetic diseases by analysis of amplified DNA sequences. $N$ Engl J Med 1987; 317: 985-990.

8. Sinclair AH, Berta P, Palmer MS, Hawkins JR, Griffiths BL, Smith MJ, Foster JW, Frischauf AM,
Lovell-Badge R, Goodfellow PN. A gene from the human sex determining region encodes a protein with homology to a conserved DNA-binding motif. Nature 1990; 346: 240-246.

9. Miller JR, Koopman M. Isolation and characterization of two male-specific DNA fragments from the bovine gene. Anim Genet 1990; 21: 77-82.

10. Sambrook J, Fritsch EF, Maniatis T. eds "Molecular Cloning" 1989; Cold Spring Harbor Laboratory Press, New York.

11. Lin C, Magnusoin T, Samols D. A rapid procedure to identify new born transgenic mice. DNA 1989; 8: 297-299.

12. Utsumi K, Kato H, Iritani A. Full-term development of bovine follicular oocytes matured in culture and fertilized in vitro. Theriogenology 1991; 35: 695-703.

13. Utsumi K, Hayashi M, Takakura R, Utaka K, Iritani A. Chromosomal analysis and the development of bovine embryos sexed by a rat malespecific antibody. J Morecul Reprod E Develop (in press).

14. Woychik RP, Camper SA, Lyon RH, Horowitz S, Goodwin EC, Rottman FM. Cloning and nucleotide sequencing of bovine growth hormone gene. Nucleic Acids Research 1982; 10: 7197-7210.

15. Tarkovsky AK. An air-drying method for chromosome preparation from mouse eggs. Cytogenetics 1966; 5: 394-400.

16. Utsumi K, Hoshi S, Tominaga K, Yuhara M. Deep freezing of cow embryos by computalized autofreezer. Proc Vth World Conf on Anim Prod in Kyoto 
1983; 2: 199-200.

17. Palmer MS, Sinclair AH, Berta P, Ellis NAA, Goodfellow PN, Abbas NE, Fellous M. Genetic evidence that ZFY is not the testis-determining factor. Nature 1989; 342: 937-939.

18. Page DC, Mosher R, Simpton EM, Fisher EMC, Mardeon G, Pollack J, McGillirvray B, de la Chapelle A, Brown LG. The sex-determining region of the human $\mathrm{Y}$ chromosome encodes a finger protein. Cell; 1987; 51: 1091-1104.

19. Nakahori Y, Mitani K, Yamada M, Nakagome Y. A human Y-chromosome specific repeated DNA family (DZY1) consists of a tandem array of pentanucleotides. Nucleic Acids Res 1986; 14: 7569-7580.

20. Weisenbach J, Goodfellow PN, Smith KD. "Report of the committee on the genetic constitution of Y chromosome" in 10th Intern. Workshop on Human gene Mapping in New Heaven. Cytogenet Cell genet 1989; 51: 439-449.

21. Miller JR. Isolation of $\mathrm{Y}$ chromosome-specific sequences and their use in embryo sexing. Reprod Dom Anim 1991, 26: 58-65.

22. Kai M, Sawamura S, Yamamoto T, Ozawa A. Simplified method for confirmation of PCR products. Nucleic Acids Res 1991, 19: 4569.

23. Peura T, Hyttinenn JM, Turunen M, Jqanne JA. Reliable sex determination assay using bovine preimplantation embryos using the polymerase chain reaction. Theriogenology 1991; 35: 547-555.

24. Her CM, Reed KC. Micromanipulation of bovine embryos for sex determination. Theriogenology 1991; 35: 45-54. 